\title{
Friction STIR WELding OF AEROSPACE MAterials: A State OF ART RevieW
}

\author{
VERMA, S., GUPTA, M.,\& MisRA, J.P.
}

Abstract: Increase in payload and fuel efficiency of aircrafts are the major issues for aviation industries and to overcome this issue manufacturing process industries are attracted towards aluminium alloys owing to its unique properties. The joining of alluminium alloys using fusion welding techniques are found defect prone. It necessitates the exploration of friction stir welding (FSW) for efficient joining of alluminium alloys. In the context of FSW, influence of parameters, mechanical and metallurgical analysis of the weld are some of the vital areas of research. In this book chapter, an attempt has been made to review the above mentioned areas and to suggest future outlook for friction stir welding of aerospace aluminium alloys.

Key words: Aerospace alloys, friction stir welding, tool geometry, mechanical analysis, metallurgical analysis
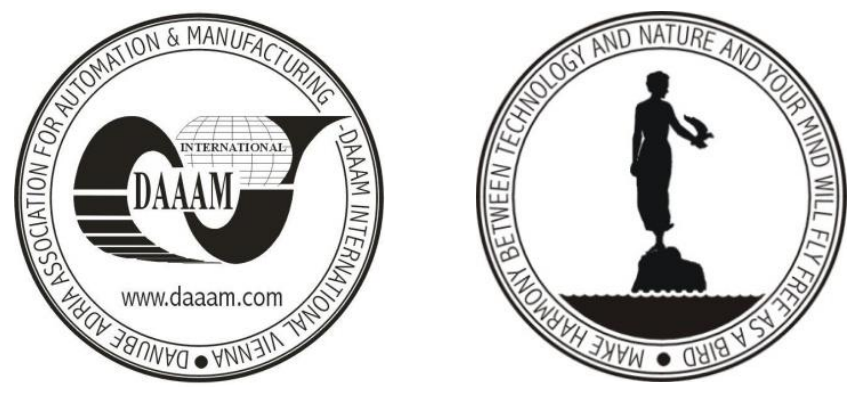

Authors' data: Verma, S[hubham], Gupta, M[eenu] \&Misra, J[oy] P[rakash], Mechanical Engineering Department, National Institute of Technology Kurukshetra, India, shubham_6140005@nitkkr.ac.in

This Publication has to be referred as: Verma, S[hubham]; Gupta, M[anish] \& Misra, J[oy] P[rakash] (2016). Friction Stir Welding of Aerospace Materials: a State of Art Review, Chapter 13 in DAAAM International Scientific Book 2016, pp.135150, B. Katalinic (Ed.), Published by DAAAM International, ISBN 978-3-90273409-9, ISSN 1726-9687, Vienna, Austria

DOI: 10.2507/daaam.scibook.2016.13 


\section{Introduction}

Weight and strength are extremely influenced factors for manufacturing parts used in aviation industries and therefore, the aviation industries are moving towards aluminium alloys owing to its unique characteristics: high strength to weight ratio, high corrosive resistance, excellent formability, easily recyclable, etc. In present day scenario aluminium alloy 2024, 6061, 6063, 6082, 7075 and 8090 are employed in aerospace applications. In AA2024 (Al-Cu Alloys), presence of copper increases the strength and hardness, in specific cases weldability. However, AA2024 is having low corrosion resistance property and hence, during application in atmosphere this is generally painted or clad. In AA6061 (Al-Mg-Si), alloying elements are magnesium and $\mathrm{Si}$. Si has no significance, but the ratio of $\mathrm{Mg}$-Si increases the strength. These alloys possess moderate strength, high corrosion resistance and excellent extrudibility. AA6063 (Al-Mg-Si), is widely used aluminium alloy owing to its extrudibility. In AA7075 (Al-Zn), zinc is used as alloying element that reduces the hot cracking and stress corrosion cracking (The Aluminium Association, Technical Report Inc., 1998). In AA8090, lithium is used as alloying element and owing to it the strength to weight ratio enhances manifold. Moreover, this alloy possesses superior fatigue crack propagation resistance. Recently, AA6063 and AA6061 has been replaced by AA6082 for aerospace applications. AA6082 is having manganese as alloying element, which increases the strength to weight ratio (Verma et al., 2015).The composition, mechanical, thermal and electrical properties of aerospace aluminium alloys are presented in Table 1 .

\begin{tabular}{|c|c|c|c|c|}
\hline Compositio & Mechanical Properties & \multicolumn{2}{|c|}{ Thermal Properties } & Electrical Resistivity \\
\hline \multirow[t]{2}{*}{$\begin{array}{l}\text { AA } \mathbf{2 0 2 4} \\
\mathrm{Al}: 93.5 \% \\
\mathrm{Cu}: 4.4 \% \\
\mathrm{Mn}: 0.6 \% \\
\mathrm{Mg}: 1.5 \%\end{array}$} & $\begin{array}{l}\text { Density : } 2.70 \mathrm{~g} / \mathrm{cc} \\
\text { Young's Modulus: } 70 \mathrm{GPa} \\
\text { Poisson's Ratio : } .3 \\
\text { Tensile Strength: } 440 \mathrm{Mpa} \\
\text { Yield Strength : } 345 \mathrm{Mpa}\end{array}$ & $\begin{array}{l}\text { Thermal } \\
\text { Expansion } \\
\text { Coefficient } \\
\left(\mu \mathrm{m} / \mathrm{m}-{ }^{\circ} \mathrm{C}\right)\end{array}$ & 23.2 & \multirow{2}{*}{$4.49 \times 10^{-6} \mathrm{ohm}-\mathrm{cm}$} \\
\hline & $\begin{array}{l}\text { Shear Strength }: 283 \mathrm{Mpa} \\
\% \text { of Elongation: } 5 \\
\text { Hardness }(\mathrm{HV}): 142\end{array}$ & $\begin{array}{l}\text { Thermal } \\
\text { Conductivity } \\
\text { (W/m-k) }\end{array}$ & 151 & \\
\hline \multirow{2}{*}{$\begin{array}{l}\text { AA } \mathbf{6 0 6 1} \\
\mathrm{Al}: 95-98 \% \\
\mathrm{Si}: 0.4- \\
0.8 \\
\mathrm{Mg}: 0.8- \\
1.2 \% \\
\mathrm{Cr}: 0.04- \\
0.3 \%\end{array}$} & \multirow{2}{*}{$\begin{array}{l}\text { Density }: 2.70 \mathrm{~g} / \mathrm{cc} \\
\text { Young's Modulus: } 69 \mathrm{GPa} \\
\text { Poisson's Ratio }: .3 \\
\text { Tensile Strength: } 290 \mathrm{Mpa} \\
\text { Yield Strength }: 255 \mathrm{Mpa} \\
\text { Shear Strength }: 186 \mathrm{Mpa} \\
\% \text { of Elongation }: 12 \\
\text { Hardness (HV) }: 107\end{array}$} & $\begin{array}{l}\text { Thermal } \\
\text { Expansion } \\
\text { Coefficient } \\
\left(\mu \mathrm{m} / \mathrm{m}-{ }^{\circ} \mathrm{C}\right)\end{array}$ & 23.6 & \multirow{2}{*}{$3.99 \times 10^{-6} \mathrm{ohm}-\mathrm{cm}$} \\
\hline & & $\begin{array}{l}\text { Thermal } \\
\text { Conductivity } \\
\text { (W/m-k) }\end{array}$ & 167 & \\
\hline
\end{tabular}




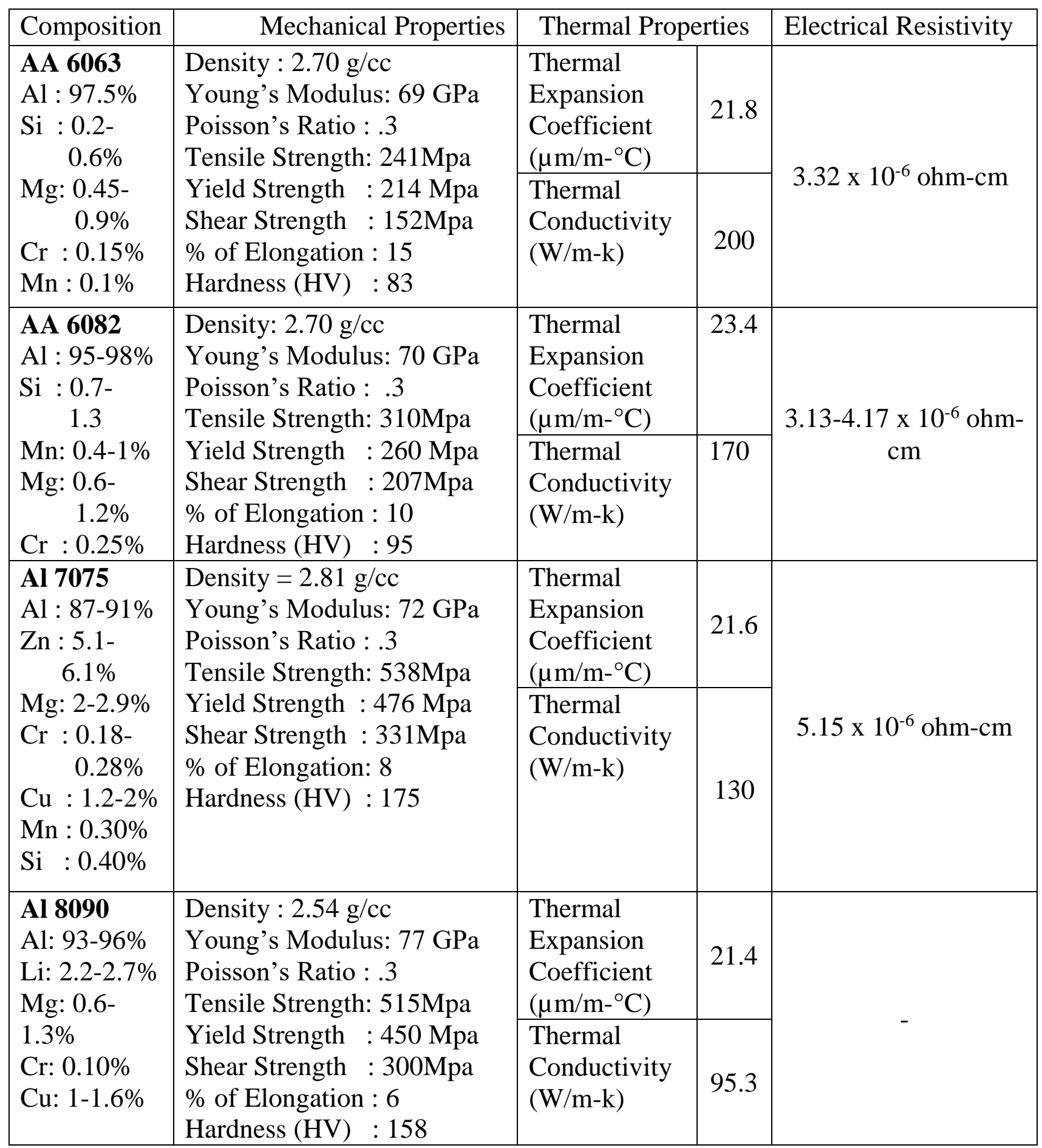

Tab.1. Composition and properties of AA2024, AA6061, AA6063, AA6082, AA7075, and AA8090 (Metals hand book, 1990; The aluminum association, Technical report Inc. From aluminum standards and data, 2015).

It is observed that the welding of these alloys by fusion welding process generally results in slag inclusions, distortion, solidification cracking, weld and voids formation in weld nugget owing to mismatch of filler material properties, aluminium oxides, hydrogen solubility, etc. (Fratini et al., 2010; Rodrigues et al., 2009; Sundaravel, 2011). To overcome these limitations, The Welding Institute (TWI) in 1991 at UK invented solid state joining process for joining high strength aluminium alloys especially for aerospace industries in order to avoid the defects that are 
obtained during welding by fusion welding process. In 1999, the USA aerospace industry used the FSW process for the welding of high-strength aluminium alloys for manufacturing of fuel tanks for spacecraft. By the application of FSW technique in spacecraft it is realized that the strength of the joint increases from $30 \%$ to $50 \%$ and manufacturing time reduces from 23 to 6 days and cost saving is upto $60 \%$ (Lohwasser \& Chen, 2010). After that the application of FSW in spacecraft tremendously increases for the fabrication of aluminium components. FSW is found to be a green technology because it is eco-friendly due to absence of harmful gases as compared to fusion welding process and its behaviour is energy efficient. The schematic diagram for friction stir welding is depicted in Figure 1.

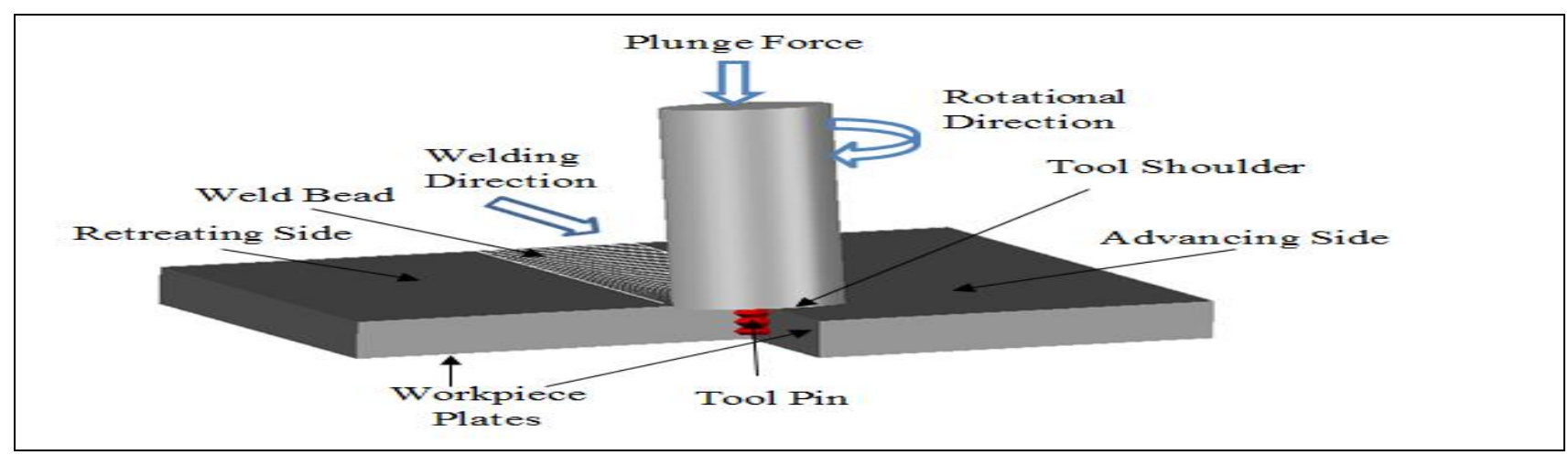

Fig. 1. Schematic diagram of friction stir welding (Verma et al., 2015)

It consists of specially designed non-consumable tool with pin and shoulder as shown in Figure 2(a). The pin plunges between faying surface of workpiece in order to enhance the movement of the material from front to back side, as well as from top to bottom. It also provides stirring action in nugget zone during the process. The common design for the pin is cylindrical or conical with or without threads or with or without flutes that influences the flow of material. The tool shoulder has surface contact with the workpiece owing to this; frictional heat is generated that provides the necessary heat for FSW process. This generated heat softens the material in nugget zone and makes its movement easier. Generally tool shoulder is cylindrical in shape with negative or positive scrolls or it can be concave or convex which influences the material movement during the process. Mechanical stirring and deformation occur along the transverse line by pin in order to produce the solid state joint with an exit hole at the end of joint as shown in Figure 2(b) (Verma\& Misra, 2015).

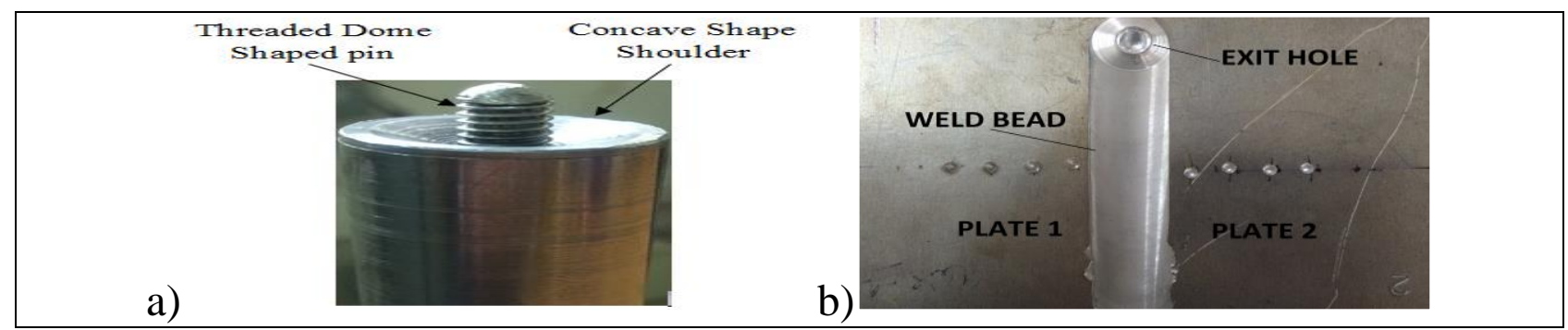

Fig. 2. (a) FSW tool; (b) welded Plates 


\section{Microstructural Regions for FSW}

In welding processes, various microstructural regions make after completion of the process. In case of fusion welding process, microstructural regions are divided into two regions: fusion zone and heat affected zone. Nevertheless in FSW process, the weld regions are divided into four primary regions: nugget zone, thermomechanical heat affected zone, heat affected zone and parent metal region. In case of FSW the microstructure obtained at nugget zone is at the order of $1.2 \mu \mathrm{m}$ but in gas tungsten arc welding (GTAW) dendritic structure is obtained (Fahimpour et al., 2012). The regions with different microstrutre obtained with FSW are shown in Figure 3. First region is nugget zone or stir zone or fully recrystallized zone, in which tool pin rotates and produces frictional heat that results in severe plastic deformation. In this region the size of grains are fine and small and are in micrometre range. As a result, ductility of weld enhances and there is also a reduction in flow stresses (Rohdes et al., 1997; Murr et al., 1998; Ma et al., 2002). Lui et al. (1997) observed that the hardness of this region increases from top surface to bottom surface of weld along with grains. However, loss in yield strength (YS) and ultimate tensile strength (UTS) is significantly less as compared to fusion welding process (Mahoney et al., 1998). The next region is thermomechanically affected zone (TMAZ) that is very near to weld nugget and it is plastically deformed by means of tool. In this region material deforms without recrystallization and size of this zone is narrow with fine and equiaxed grains. Tensile strength and hardness is found to be inferior than base metal in TMAZ (Hwang et al., 2008). The next region is heat-affected zone that is next to TMAZ and is affected by heat but no plastic deformation takes place in this region; however, mechanical and microstructural property changes. The grains size in the HAZ is same as that of the base metal. Fatigue crack growth resistance in HAZ is found superior as compared to weld nugget zone (Jata et al., 2000). Fourth microstructural region is parent metal region which is unaffected by heat as it is far away from the recrystallized zone and hence microstructure and mechanical properties of this region remains unaltered. (Zhang \& Zhang, 2007; Threadgill, 2007; Xu et al., 2012).

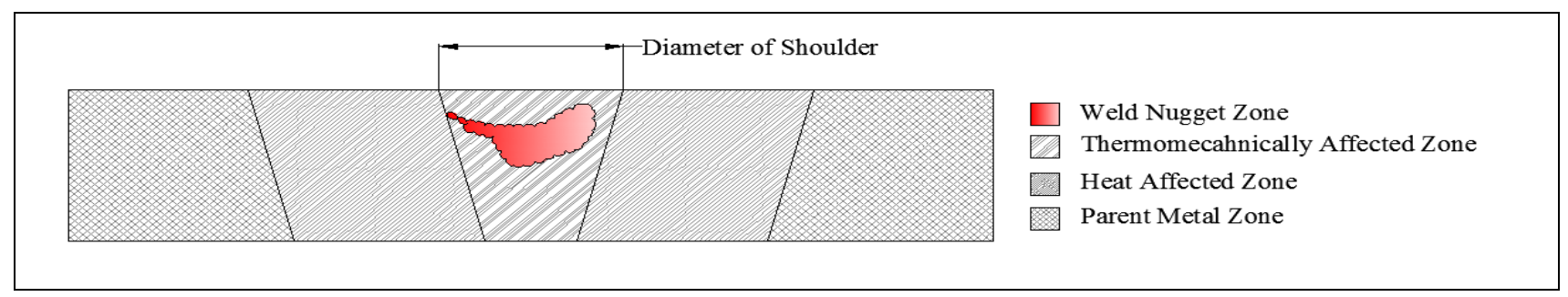

Fig. 3. Various Regions of FSW

\section{Experimental Details}

Verma et al. 2016 modified the conventional vertical milling machine into friction stir welding setup for developing experimental setup for FSW. The schematic diagram of the experimental setup for the friction stir welding is depicted in Figure 4. 
This process involves frictional heating, rotational and translational movement of tool, plunge force, etc. and hence, strength, heat resistance capability, good machinability, easy availability and low cost should be taken into consideration during selection of material for fabricating the machine setup. The machine setup for FSW consists of four major subsystems namely (a) tool and tool holding system; (b) workpiece holding system; (c) motion supply system and (d) machine frame. Tool and tool holding system consists of rotating FSW tool and a quill to hold the tool. The workpiece holding system contains a specially designed and shaped fixture to hold the workpieces properly. Fixture consists of base plate and clamps and it helps to keep the faying surface in contact during the process. Motion supply system consists of motors to provide rotational motion to the FWS tool and translational motion to the workpiece. Machine frame consists of bed for holding the fixture, spindle head to hold the quill, a vertical column and knee elevating screw for positioning of bed and to provide necessary support to the machine setup (Verma \& Misra, 2015).

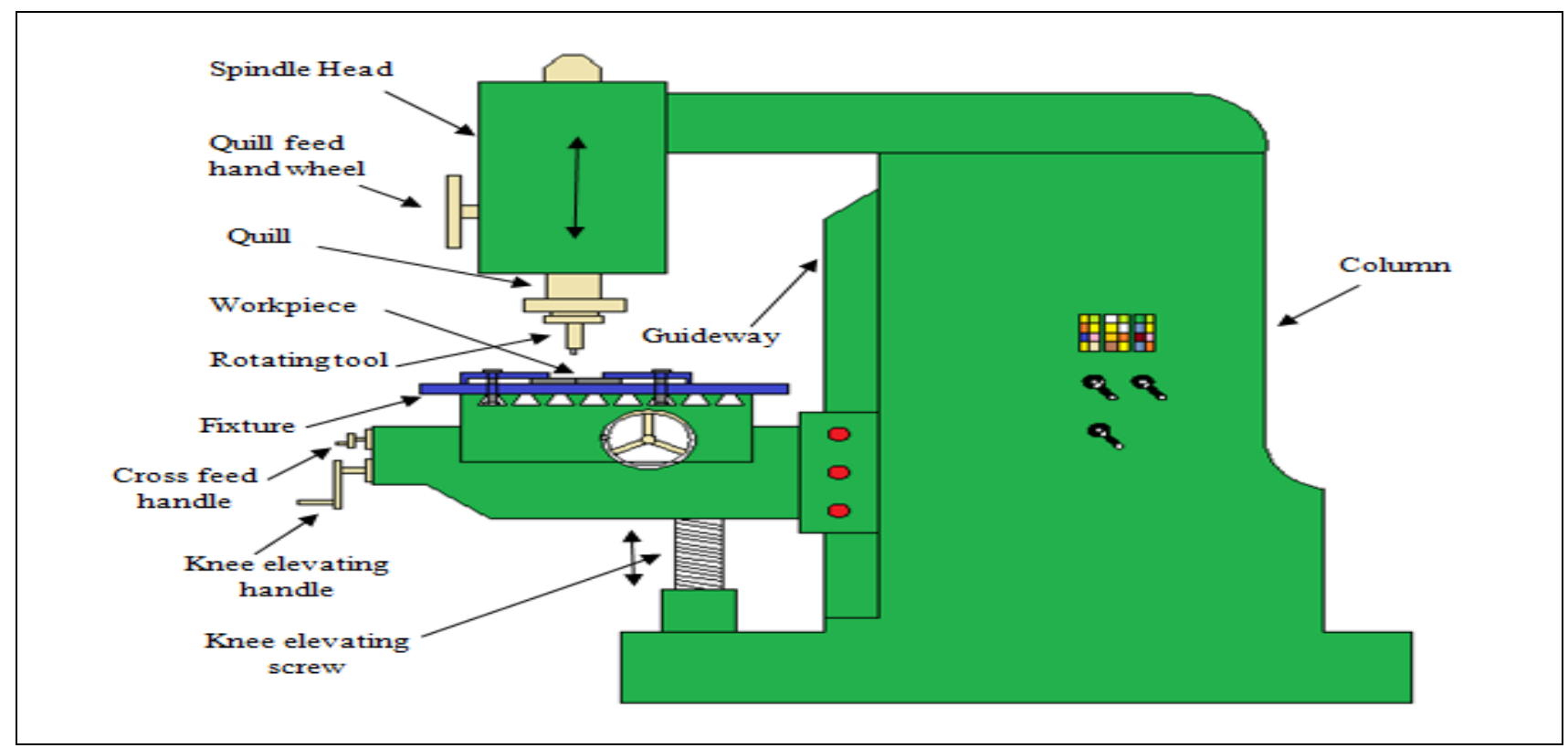

Fig. 4. Schematic Diagram for Friction Stir welding

\section{Process Parameters}

The process parameters for FSW are broadly classified into three groups:

a) Tool related parameters: shoulder profile, pin profile, shoulder and pin diameter, shoulder and pin material, etc.

b) Machine related parameters: welding speed, rotational speed, tilt angle, etc.

c) Other parameters: workpiece properties, anvil size, workpiece size, anvil material, etc.

The cause and affect diagram of process parameters of FSW is depicted in Figure 5 (Lohwasser \& Chen, 2010; Verma \& Misra, 2015). Numerous researchers have carried out extensive research work on FSW of aerospace alloys to experimentally investigate the influence of process parameters on FSW weld. Their 
findings are concluded in this book chapter to provide a guideline to future user for efficient use of the technique for joining of aerospace alloys.

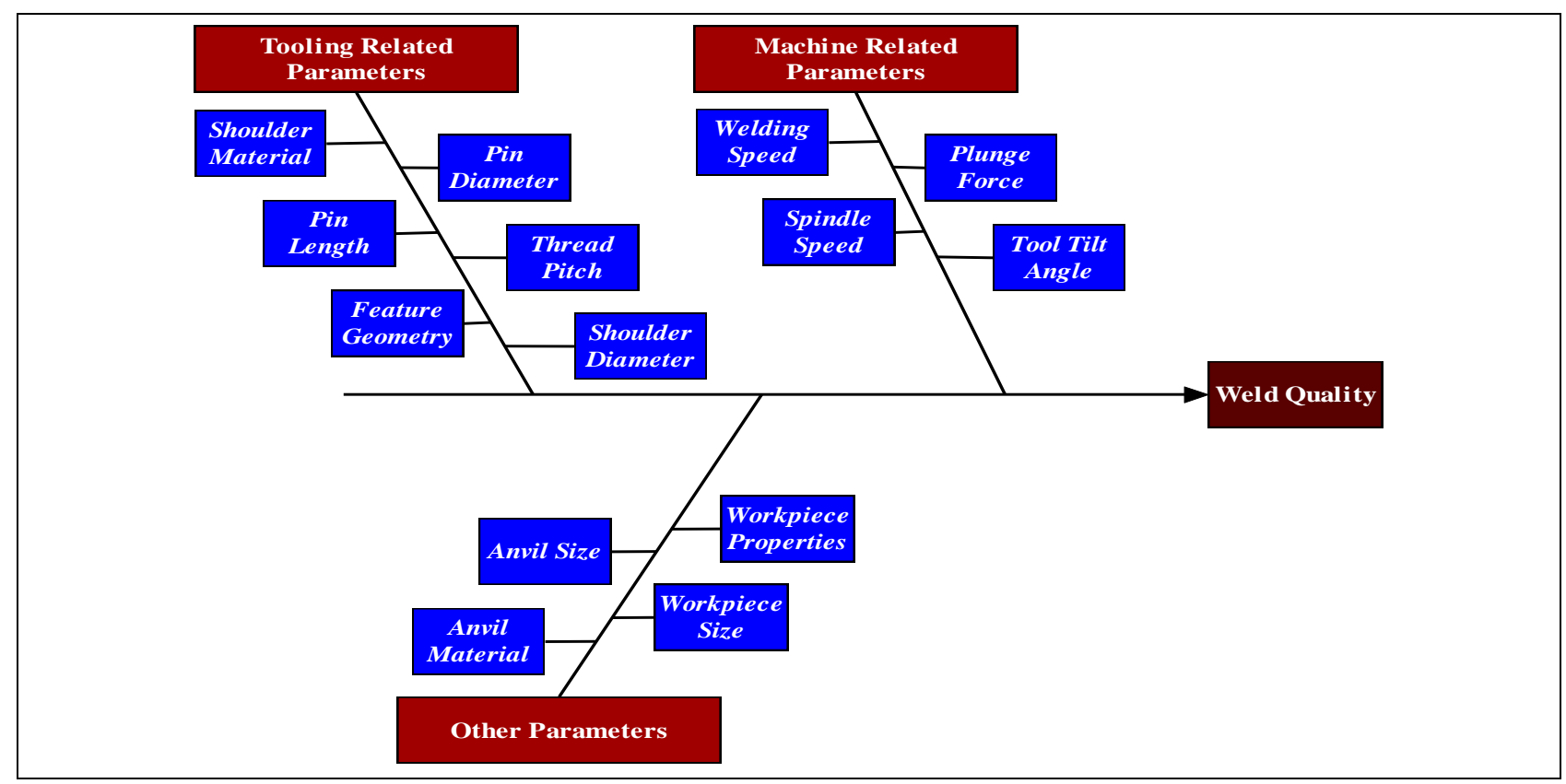

Fig. 5. Cause and effect diagram for friction stir welding process

\subsection{Effect of Tool Related Parameters}

The entire process depends on the tool related parameters which produce required frictional heat for weld. This frictional heat softens the surrounding material around the tool resulting in recirculation of plasticized material near tool surface and produces solid state joint (Kumar \& Murugan, 2014). The FSW tool consists of shoulder and pin. Tool shoulders are crucial element for producing essential amount of heat for FSW process. Heat is generated due to friction and material deformation between the rotating shoulder surface and workpiece. It also controls the flowing metal beneath the surface of shoulder in the nugget zone. Tool shoulder may be flat, concave or convex, etc. The different profiles for shoulder surfaces are presented in Table 3. The primary function of tool pin is to stir the soften material between the faying surfaces and move it to produce solid state joint. The lower surface of tool pin may be flat or domed. The different surface profiles for pin are presented in table 4 . Trimble et al. (2015) employed FSW process for butt joining of AA2024 with scroll shoulder and triflute pin. It was concluded that scroll shoulder and triflute pin profile produces good qulaity weld at lower rpm speed with higher feed rate. Elangovan \& Balasubramanian (2008) used FSW process for welding AA6061 and reported that pin profiles with square and traingular shapes generally produces good quality weld owing to pulsating strring in the nugget zone.

\subsection{Effect of Machine Related Parameters}

Rotational speed, welding speed or feed rate, plunge force and tilt angle are machine related parameters. The main role of rotational speed is to generate the frictional heat between the workpiece and tool surface. It affects the mechanical and metallurgical properties of FSW weld. The higher rotational speed produces 
sufficient amount of heat for consolidation of material. Sometimes higher rotational speed generate more heat than required and causes turbulent flow in nugget zone resulting in microlevel voids in stir zone with poor strength. Conversely lower rotational speed produces inadequate friction which leads to poor material deformation and poor ultimate tensile strength. (Azimzadegan \& Serajzadeh, 2010; Dinaharan \& Murugan, 2012; Heidarzadeh et al., 2012). Zhang \& Zhang, (2009) employed FSW technique to join AA6061 and observed that higher rotational speed with lower welding speed produces higher quality weld. In weld nugget zone, the grain size changed according to rotational speed; larger the speed smaller the grains size and hence, strength increased (Zhang \& Zhang, 2007). Suresha et al. (2011) carried out experimental investigation on FSW of AA7075 plates. It was concluded that rotational speed is more dominant factor than the other factors for tensile strength.

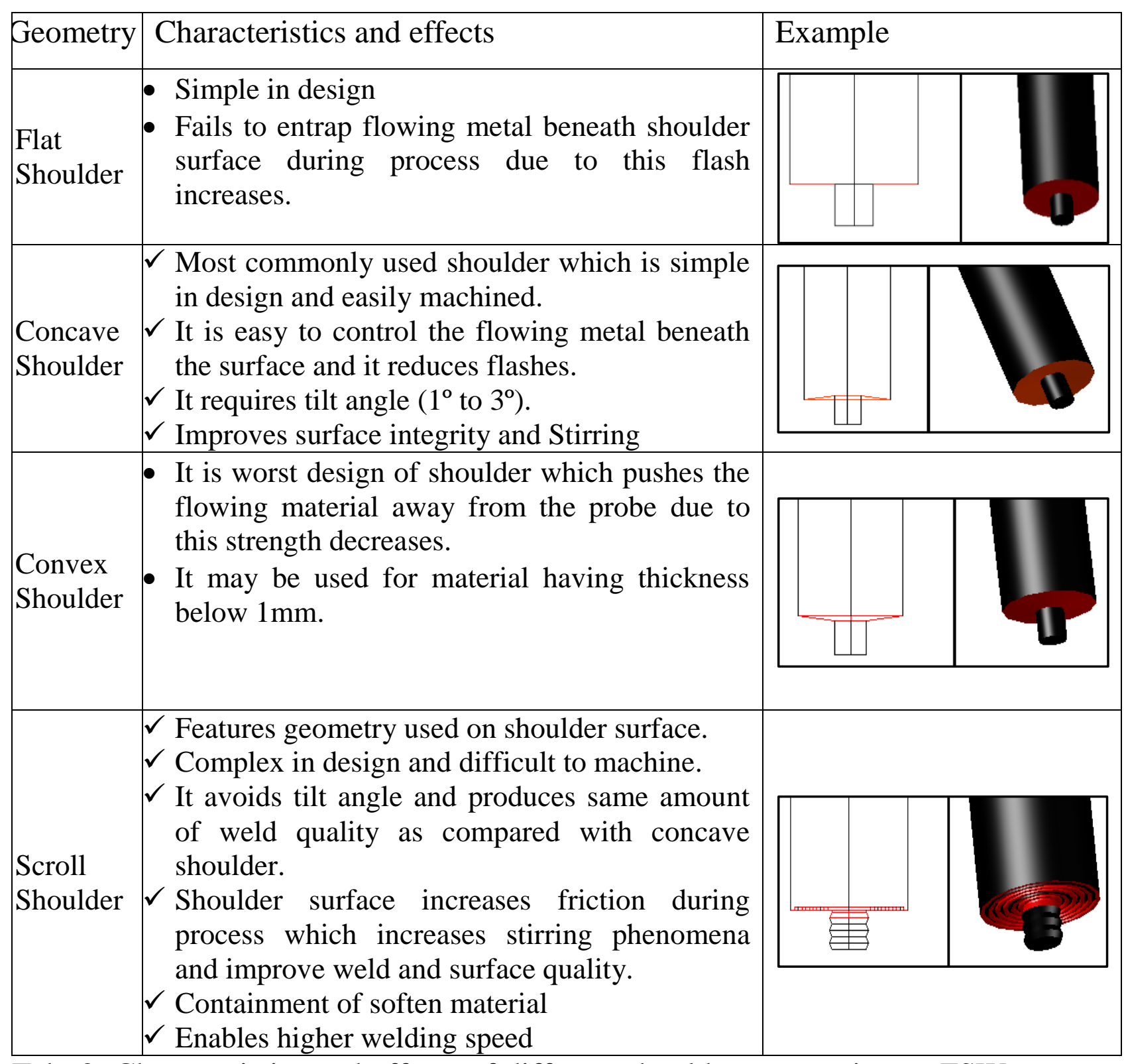

Tab. 2. Characteristics and effects of different shoulder geometries on FSW process. (Misra \&Mahoney, 2008; Rodrigues et al., 2009; Trimble et al., 2015; Trueba et al., 2015). 
Welding speed or feed rate is the speed at which the tool travels along the length of the weld. Heat input per unit length of weld decreases with increase in welding speed so no proper stirring takeplace in nugget zone resulting in inferior tensile strength. Higher welding speed also creates voids in the nugget zone as the grain size increses with increase in welding speed with presence of weld flaw. Conversely at lower welding speed fine grain structure is obtained owing to proper stirring in nugget zone. It also leads to reduction in strength of weld owing to improper consolidation of material (Elangovan \& Balasubramanian, 2008; Zhang \& Zhang, 2009; Shen et al., 2010; Dinaharan \& Murugan, 2012). It is observed that the forces on pin increases with increase in transverse speed (Ulysse, 2002). Tool tilt angle is the inclination of tool axis along the transverse direction of welding. It has influences on heat input, stirring process, filling of material in weld bead and material flow process during FSW. When tool tilt angle is very small $\left(\alpha \leq 1.5^{\circ}\right)$ is the problem of lifting of tool due to presence of plasticized material beneath the tool surface take place that causes voids and non-adequate flow of materials in nugget zone. If it is $\geq 4$ $.5^{\circ}$, the shoulder cavity cannot contain the material resulting in poor strength, tunnel defect and weld flashes (Chen et al., 2006).

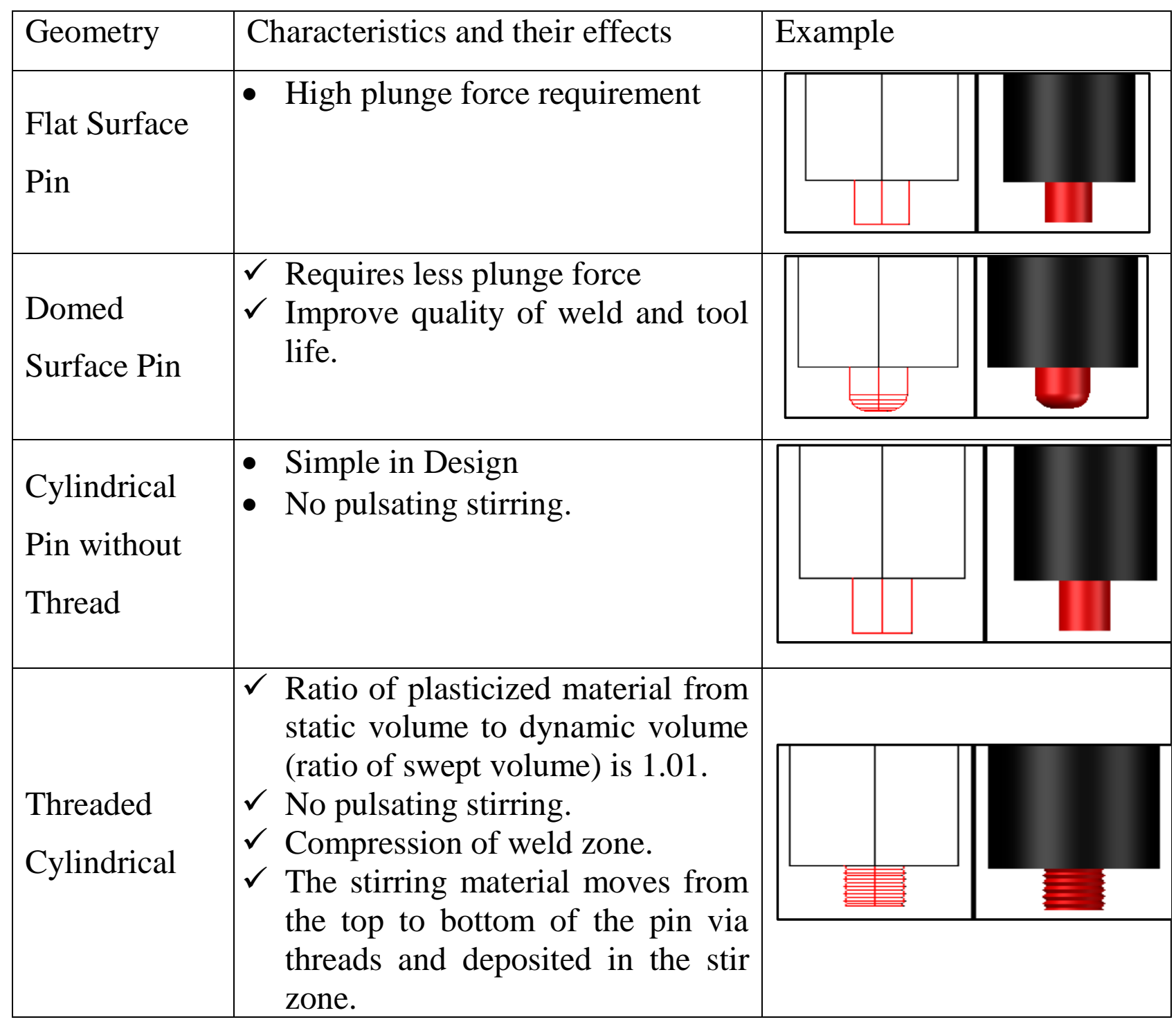


Verma, S.; Gupta, M. \& Misra, J. P.: Friction Stir Welding of Aerospace Materials: a

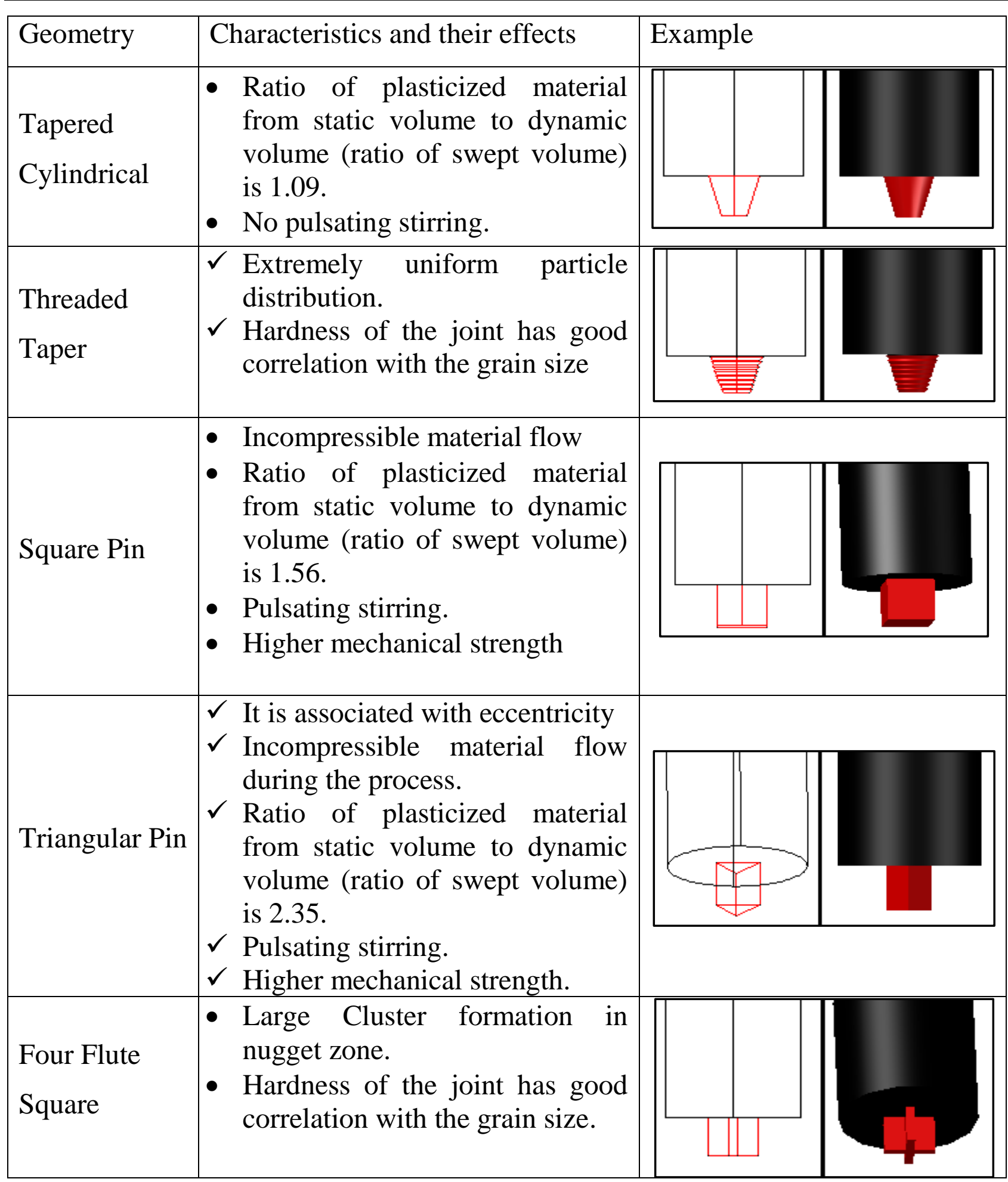

Tab. 3. Characteristics and effects of different pin geometries on FSW process. (Thomas \& Nicholas, 1997; Colligan, 1999; Misra \& Mahoney, 2008; Elangovan \& Balasubramanian, 2008; Karthikeyan \& Balasubramanian, 2010; Roshan et al., 2013; Bahrmi et al., 2014).

\subsection{Effect of Other Parameters}

Other parameters namely workpiece size and properties, anvil size and material, etc. also play a vital role in FSW. Bahrami et al. (2014) reported the effect of presence of foreign particles in the stir zone on the strength of FS welded AA7075. The mechanical strength and elongation are enhanced by $76.1 \%$ and $31 \%$ 
respectively owing to the presence of $\mathrm{SiC}$ particles in the stir zone. Zhao et al. (2015) fabricated the surface composite layer by using $\mathrm{B}_{4} \mathrm{C}$ particles during friction stir processing of AA6061. It was evident that the uniformity of the $\mathrm{B}_{4} \mathrm{C}$ particles are increased with increase in number of passes during the process It results in enhancement of resistance to wear and microhardness of the nugget zone. Misak et al. (2014) employed FSW for joining of AA2024 plates and observed that tensile strength remains same on the advancing side whereas elongation reduces in the longitudinal direction. The size and material of anvil depend on the workpiece properties and shapes. Upadhyay and Reynolds (2014) carried out experimental investigation on FS welded $25 \mathrm{~mm}$ thick AA6061 plates using four different backing plates and explained the effect of backing plate on the process performance. It was concluded that the thermal properties of backing plate play a crucial role in determining the size of the grains in the nugget zone resulting in alteration of mechanical and metallurgical propertie of the weld.

\section{Summary and Future Outlook}

A critical analysis of FSW of aerospace aluminium alloys has been carried out. On the basis of critical evaluation of the available literature following conclusions are summarised.

- Four different microstructural regions have been identified in the FS weld, i.e. stir zone, TMAZ, HAZ, and parent metal. Stir zone is fully recrystallized zone that contains fine and equiaxed recrystallized grains as compared to other regions. Second region is affected by the less heat as compared to nugget zone and plastic deformation also takes place in this region. TMAZ is weaker in strength as compared to nugget zone and fracture also occurs in this zone during tensile test. Third region is HAZ which is affected by the heat during the process without any plastic deformation.

- The region for nugget zone formed by FSW is very narrow as compared to fusion welding process resulting in sound quality weld. There is no melting of materials during FSW that minimizes the chance of solidification defects. Two dissimilar aerospace alloys can easily be joined with less number of defects as compared to fusion welding process. Moreover, the strength of joint of dissimilar alloys is found superior in case of FSW.

- Process parameters such as feed rate, rotational speed, tool geometry, tool tilt angle and plunge depth influence the quality of weld. The role of tool geometry is very important for the movement of material and the plastic deformation during the process. The tool pin produces the stirring action and intense heating in the stir zone resulting in change in grain size. During FSW, fine recrystallized grains improve the strength and hardness of the joint as compared to fusion welding process.

- The shoulder diameter should be three times pin diameter for obtaining good quality weld. 
Verma, S.; Gupta, M. \& Misra, J. P.: Friction Stir Welding of Aerospace Materials: a

- The weld strength, percentage of elongation, fatigue strength, yield strength, microhardness obtained in FSW of aerospace alloys are found on higher side as compared to fusion welding processes of these alloys.

Furthermore, the process parameters employed in FSW of aerospace alloys are summarized in Table 4 for providing a guideline to the future users. This process has plenty of scope for future research which may include preheating of workpiece, nanoparticle inclusions, quenching, etc. In addition, FSW of aluminium lithium alloys require proper attention as it is having very high strength to weight ratio and huge potential to replace other aerospace materials.

\begin{tabular}{|c|c|c|c|c|c|c|c|c|c|}
\hline \multicolumn{2}{|c|}{ Workpiece } & \multicolumn{5}{|c|}{ Tool related parameters } & \multicolumn{3}{|c|}{ Input parameters } \\
\hline Material & Th & SD & PD & PL & $\mathrm{TM} / \mathrm{TA} / \mathrm{TO}$ & PG & $\mathrm{RS}$ & FD & $\mathrm{AF}$ \\
\hline $\begin{array}{c}\text { AA202 } \\
4 \text { AA } 70 \\
75 \\
\end{array}$ & 2.5 & 20 & 6 & 2.5 & $3^{0}$ & $\mathrm{C}$ & 700 & 160 & - \\
\hline $\begin{array}{l}\text { AA606 } \\
1 / \mathrm{AlN}_{\mathrm{p}}\end{array}$ & 6 & 18 & 6 & 5.7 & $\begin{array}{l}\text { High carbon, } \\
\text { high chromium } \\
\text { steel }\end{array}$ & SQ & $\begin{array}{l}1000- \\
1400\end{array}$ & $25-85$ & $3-7$ \\
\hline $\begin{array}{c}\text { AA606 } \\
1\end{array}$ & 6 & $15-21$ & 6 & 5.5 & $\begin{array}{l}\text { High carbon } \\
\text { steel }\end{array}$ & $\mathrm{C}$ & 1200 & 75 & 7 \\
\hline $\begin{array}{l}\text { AA606 } \\
1-T 6\end{array}$ & 3.1 & 12 & $\begin{array}{l}3.0 \mathrm{U} \\
3.7 \mathrm{~L}\end{array}$ & 2.8 & $\begin{array}{l}\text { High speed } \\
\text { steel/1 } 1^{0}\end{array}$ & $\mathrm{TC}$ & $\begin{array}{l}400- \\
1200\end{array}$ & $20-60$ & - \\
\hline $\begin{array}{c}\mathrm{AA} 606 \\
1+20 \% \\
\mathrm{Al}_{2} \mathrm{O}_{3} \\
\end{array}$ & 5 & 19 & 6.3 & - & $\begin{array}{c}\text { Tool steel (62 } \\
\text { HRC) } / 1^{0}\end{array}$ & $\mathrm{TC}$ & 1000 & $60-540$ & - \\
\hline $\begin{array}{c}\text { AA606 } \\
1\end{array}$ & 6.3 & 12.5 & 6.3 & 5.8 & Carbon Steel & $\mathrm{C}$ & $\begin{array}{c}300 \\
- \\
1000\end{array}$ & $90-150$ & - \\
\hline $\begin{array}{l}\text { AA606 } \\
1 / 7075\end{array}$ & 6.3 & 15 & 5 & - & $2.5^{0}$ & TT & 1200 & $120-300$ & 12 \\
\hline $\begin{array}{c}\text { AA608 } \\
2\end{array}$ & 4 & 14 & 6 & 3.9 & $3^{0}$ & $\mathrm{C}$ & 1600 & $40-460$ & - \\
\hline $\begin{array}{c}\text { AA608 } \\
2 \\
\end{array}$ & 5 & 15 & $\begin{array}{l}6.1 \mathrm{U} \\
3.5 \mathrm{~L} \\
\end{array}$ & 4.64 & $2.5^{0}$ & $\mathrm{TT}$ & $\begin{array}{l}800, \\
1200 \\
\end{array}$ & 200 & - \\
\hline $\begin{array}{c}\text { AA707 } \\
5\end{array}$ & 3 & $\begin{array}{r}3 d \\
8-20\end{array}$ & d & 2.8 & $\begin{array}{l}\text { H13 Steel } \\
(50 \mathrm{HRC})\end{array}$ & $\mathrm{T}$ & $\begin{array}{l}550- \\
1550\end{array}$ & $15-100$ & - \\
\hline $\begin{array}{c}\text { AA707 } \\
5 / \mathrm{SiC}\end{array}$ & 6 & 18 & $\begin{array}{l}6 \mathrm{U} \\
4 \mathrm{~L}\end{array}$ & 5.7 & $\begin{array}{l}\text { H13 Steel } \\
50 \mathrm{HRC}\end{array}$ & $\begin{array}{l}\text { TTT } \\
\text { r SQ } \\
\text { FFS } \\
\text { FFC }\end{array}$ & 1250 & 40 & - \\
\hline
\end{tabular}




\begin{tabular}{|c|c|c|c|c|c|c|c|c|c|}
\hline Material & Th & SD & PD & PL & TM/TA/TO & PG & RS & FD & AF \\
\hline $\begin{array}{c}\text { AA606 } \\
1780 / 80 \\
0 \text { steel }\end{array}$ & $\begin{array}{c}1.5 \\
\& \\
1.4\end{array}$ & 12.7 & $\begin{array}{c}3.9 \mathrm{U} \\
4.7 \mathrm{~L}\end{array}$ & 1.2 & $\begin{array}{c}\text { Tungsten } \\
\text { carbide with } \\
10 \% \text { cobalt }\end{array}$ & $\mathrm{T}$ & $\begin{array}{c}1200- \\
1800\end{array}$ & $30-120$ & - \\
\hline $\begin{array}{c}\text { AA707 } \\
5\end{array}$ & 5 & $9-21$ & $3-7$ & & $\begin{array}{c}\text { High carbon } \\
\text { steel and high } \\
\text { speed steel }\end{array}$ & TC & $\begin{array}{c}900- \\
1800\end{array}$ & $20-100$ & $\begin{array}{c}6- \\
10\end{array}$ \\
\hline $\begin{array}{c}\text { AA707 } \\
\text { 5AA20 } \\
24\end{array}$ & $\begin{array}{c}1.5 \\
\&\end{array}$ & 19 & 6.3 & - & H13 steel & TC & $\begin{array}{c}500- \\
2000\end{array}$ & $50-1000$ & - \\
\hline $\begin{array}{c}\text { AA809 } \\
0\end{array}$ & 5 & 19 & - & - & $\begin{array}{c}\text { Flat quenched } \\
\text { steel with 2 }\end{array}$ & TT & $\begin{array}{c}230- \\
460\end{array}$ & 115,170 & - \\
\hline
\end{tabular}

Tab. 4. Process parameters for FSW of AA2024, AA6061, AA6082 and AA7075.

Whereas, RS: rotational speed in RPM; FD: feed rate in $\mathrm{mm} / \mathrm{min}$; SD: shoulder diameter in mm; PD: pin diameter in mm; PL: pin length in mm; TM: tool material; TA: tool angle in degree; TO: tool offset in mm; PG: pin geometry; Th: thickness of Workpiece in $\mathrm{mm}$; AF: axial force in $\mathrm{kN}$; SQ: square cylindrical; $\mathrm{T}$ : tapered; TT: threaded taper; Tr: Triangular; FFS: four flute square; FFC: four flute cylindrical; TC: threaded cylindrical; C: cylindrical: $\mathrm{U}$ : upper diameter of taper pin and L: lower diameter of taper pin.

\section{References}

Aluminium Alloy Selection and Applications, Technical Report, the Aluminium Association, Inc., 1998

Azimzadegan, T. \& Serajzadeh, S. (2010). An Investigation into Microstructures and Mechanical Properties of AA7075-T6 during Friction Stir Welding at Relatively High Rotational Speeds, Journal of Materials Engineering and Performance,19, 1256-1263

Bahrami, M., Kazem, M., Givi, B., Dehghani, K., \& Parvin, N. (2014). On the Role of Pin Geometry in Microstructure and Mechanical Properties of AA7075 / SiC nanoComposite Fabricated by Friction Stir Welding Technique, Materials and Design, 53, 519-527

Cavaliere, P., \& Cerri, E. (2005). Mechanical Response of 2024-7075 Aluminium Alloys Joined by Friction Stir Welding, Journal of Materials Science, 40, 3669-3676 Cavaliere, P., Squillace, a., \& Panella, F. (2008). Effect of Welding Parameters on Mechanical and Microstructural Properties of AA6082 joints Produced by Friction Stir Welding, Journal of Materials Processing Technology, 200(1-3), 364-372

Chen, Y., Liu, H., \& Feng, J. (2006). Friction Stir Welding Characteristics of Different Heat-Treated-State 2219 Aluminum Alloy Plates, Materials Science and Engineering A, 420, 21-25

Colligan, K. (1999). Material Flow Behavior during Friction Stir Welding of Aluminum, Welding Research Supplement, 229s-237s

Dinaharan, I. \& Murugan, N. (2012). Optimization of Friction Stir Welding Process 
Verma, S.; Gupta, M. \& Misra, J. P.: Friction Stir Welding of Aerospace Materials: a

to Maximize Tensile Strength of AA6061 / ZrB 2 In-Situ Composite Butt Joints, Met. Mater. Int., 18(1), 135-142

Dubourg, L., Merati, A., \& Jahazi, M. (2010). Process Optimization and Mechanical Properties of Friction Stir Lap Welds of 7075-T6 Stringers on 2024-T3 skin, Materials and Design, 31, 3324-3330

Elangovan, K., \& Balasubramanian, V. (2008). Influences of Tool Pin Profile and Tool Shoulder Diameter on the Formation of Friction Stir Processing Zone in AA6061 Aluminium Alloy, Materials \& Design, 29, 362-373

Elangovan, K., \& Balasubramanian, V. (2008). Influences of Tool Pin Profile and Welding Speed on the Formation of Friction Stir Processing zone in AA2219 aluminium alloy, journal of materials processing technology, 200, 163-175

Elangovan, K., Balasubramanian, V., \& Valliappan, M. (2008). Influences of Tool Pin Profile and Axial Force on the Formation of Friction Stir Processing Zone in AA6061 Aluminium Alloy, Int J Adv Manuf Technol, 38, 285-295

Fahimpour, V., Sadrnezhaad, S. K., \& Karimzadeh, F. (2012). Corrosion behavior of aluminum 6061 alloy joined by friction stir welding and gas tungsten arc welding methods, Materials \& Design, 39, 329-333

Fratini, L., Buffa, G., \& Shivpuri, R. (2010). Mechanical and Metallurgical Effects of in Process during Friction Stir Welding of AA7075-T6 Butt Joints, Acta Materialia, 58, 2056-2067

Guo, J. F., Chen, H. C., Sun, C. N., Bi, G., Sun, Z., \& Wei, J. (2014). Friction Stir Welding of Dissimilar Materials between AA6061 and AA7075 Al Alloys Effects of Process Parameters, Materials and Design, 56, 185-192

Heidarzadeh, A., Khodaverdizadeh, H., Mahmoudi, A., \& Nazari, E. (2012). Tensile Behavior of Friction Stir Welded AA 6061-T4 Aluminum Alloy Joints, Materials \& Design, 37, 166-173

Huang, Y., Wang, Y., Wan, L., Liu, H., Shen, J., Dos Santos, J. F., \& Feng, J. (2016). Material-flow behavior during friction-stir welding of 6082-T6 aluminum alloy, International Journal of Advanced Manufacturing Technology, 1-9

Hwang, Y., Kang, Z., Chiou, Y., \& Hsu, H. (2008). Experimental study on temperature distributions within the workpiece during friction stir welding of aluminum alloys, International Journal of Machine Tools \& Manufacture, 48, 778787

International Alloy Designations and Chemical Composition Limits for Wrought Aluminum and Wrought Aluminum Alloys, Technical Report, the Aluminum Association, Inc. (2015)

Jata, K. V, Sankaran, K. K., \& Ruschau, J. J. (2000). Friction Stir Welding Effects on Microstructure and Fatigue of Aluminum Alloy 7050-T7451, Metallurgical and Materials Transactions A, 31, 1955-1964

Karthikeyan, R., \& Balasubramanian, V. (2010). Predictions of the optimized friction stir spot welding process parameters for joining AA2024 aluminum alloy using RSM, Int J Adv Manuf Technol, 51, 173-183

Kumar, B. A., \& Murugan, N. (2014). Optimization of Friction Stir Welding Process Parameters to Maximize Tensile Strength of Stir Cast AA6061-T6 / AlNp Composite, Journal of Materials \& Design, 57, 383-393 
Lertora, E., \& Gambaro, C. (2010). AA8090 Al-Li Alloy FSW Parameters to Minimize Defects and Increase Fatigue Life, International Journal of Material Forming, 3, 1003-1006

Liu, G., Murr, L. E., Niou, C.-S., McClure, J. C., \& Vega, F. R. (1997). Microstructural Aspects of the Friction Stir Welding of 6061-T6 Aluminum, Scripta Materialia, 37, 355-361

Liu, X., Lan, S., \& Ni, J. (2014). Analysis of Process Parameters Effects on Friction Stir Welding of Dissimilar Aluminum Alloy to Advanced High Strength Steel, Materials and Design, 59, 50-62

Lohwasser, D. \& Chen, Z. (2010). Friction stir welding: from basics to applications, Woodhead Publishing limited, New Delhi

Ma, Z., Mishra, R., \& Mahoney, M. (2002). Superplastic Deformation Behaviour of Friction Stir Processed 7075Al alloy, Acta Materialia, 50(17), 4419-4430

Mahoney, M. W., Rhodes, C. G., Flintoff, J. G., Spurling, R. A., \& Bingel, W. H. (1998). Properties ofFriction-Stir-Welded 7075 T651 Aluminum, Metallurgicaland Materials Transactions A, 29, 1955-1964

Metals Handbook, (1990), Properties and Selection: Nonferrous Alloys and SpecialPurpose Materials, ASM International Handbook Committee

Misak, H. E., Street, E. S. J., \& City, R. (2014). Fabrication and Characterization of Carbon Nanotube Nanocomposites into 2024-T3 Al Substrates Via Friction Stir Welding Process, Journal of Engineering Materials and Technology, 136, 3-7

Mishra, R. S. \& Mahoney, M. W. (2008). Friction stir welding and processing, ASM International, Ohio

Murr, L. E., Li, Y., Flores, R. D., Trillo, E. a., \& McClure, J. C. (1998). Intercalation Vortices and Related Microstructural Features in The Friction-Stir Welding of Dissimilar Metals, Materials Research Innovations, 2(3), 150-163

Prado, R. A., Murr, L. E., Soto, K. F., \& Mcclure, J. C. (2003). Self-Optimization in Tool Wear for Friction-Stir Welding of Aluminium Al6061+20\% $\mathrm{Al}_{2} \mathrm{O}_{3} \mathrm{MMC}$, Materials Science and Engineering, 349, 156-165

Rajakumar, S., Muralidharan, C., \& Balasubramanian, V. (2011). Influence of Friction Stir Welding Process and Tool Parameters on Strength Properties of AA7075-T 6 Aluminium Alloy Joints, Materials and Design, 32, 535-549

Rhodes, C. G., Mahoney, M. W., Bingel, W. H., Spurling, R. A., \& Bampton, C. (1997). Effects of Friction Stir Welding on Microstructureof 7075 Aluminum, Scripta Materialia, 36, 69-75

Rodrigues, D. M., Loureiro, a., Leitao, C., Leal, R. M., Chaparro, B. M., \& Vilaça, P. (2009). Influence of Friction Stir Welding Parameters on the Microstructural and Mechanical Properties of AA 6016-T4 Thin Welds, Materials \& Design, 30(6), 1913-1921

Roshan, B. S., Jooibari, B. M., Teimouri, R., Asgharzadeh-Ahmadi, G., FalahatiNaghibi, M., \& Sohrabpoor, H. (2013). Optimization of Friction Stir Welding Process of AA7075 Aluminum Alloy to achieve desirable Mechanical Properties using ANFIS Models and Simulated Annealing Algorithm. International Journal of Advanced Manufacturing Technology, 69, 1803-1818 
Verma, S.; Gupta, M. \& Misra, J. P.: Friction Stir Welding of Aerospace Materials: a

Shen, J. J., Liu, H. J., \& Cui, F. (2010). Effect of Welding Speed on Microstructure and Mechanical Properties of Friction Stir Welded Copper, Materials \& Design, 31, 3937-3942

Sundaravel, V. (2011). Process Optimization for Friction Stir Welding: On AA 5083 for Marine Applications, VDM Verlag Dr. Müller, 978-3639343915

Suresha, C. N., Rajaprakash, B. M., \& Upadhya, S. (2011). A Study of the Effect of Tool Pin Profiles on Tensile Strength of Welded Joints Produced Using Friction Stir Welding, Materials and Manufacturing Processes, 26, 1111-1116

Thomas W. M., \& Nicholas, E. D. (1997). Friction Stir Welding for the Transportation Industries, Mater Des, 229s-37s

Threadgill, P.L. (2007). Terminology in Friction Stir Welding, Science and Technology of Welding and Joining, 12, 4, 357-432

Trimble, D., Mitrogiannopoulos, H., O’Donnell, G. E., \& McFadden, S. (2015). Friction Stir Welding of AA2024-T3 Plate - The influence of different pin types, Mechanical Sciences, 6(1), 51-55

Trueba, L., Heredia, G., Rybicki, D., \& Johannes, L. B. (2015). Effect of tool shoulder features on defects and tensile properties of friction stir welded aluminum 6061-T6. Journal of Materials Processing Technology, 219, 271-277

Ulysse, P. (2002). Three-dimensional Modeling of the Friction Stir-Welding Process. International Journal of Machine Tools and Manufacture, 42, 1549-1557

Upadhyay, P., \& Reynolds, A. (2013). Effect of Backing Plate Thermal Property on Friction Stir Welding of 25-mm-Thick AA6061, Metallurgical and Materials Transactions A, 45, 2091-2100

Verma, S., \& Misra, J.P. (2015). A Critical Review of Friction Stir Welding Process, Daaam International Scientific Book, 249-266

Verma, S., Meenu, \& Misra, J.P. (2015). Study on temperature distribution during Friction Stir Welding of 6082 aluminum alloy, 5th International Conference on Material Processing and Characterization, GRIET, 12-13 March, 2016, Hyderabad, India

Xu, X., Yang, X., Zhou, G., \& Tong, J. (2012). Microstructures and Fatigue Properties of Friction Stir Lap Welds in Aluminum Alloy AA6061-T6, Materials \& Design, 35, 175-183

Zhang, Z., \& Zhang, H. W. (2007). Material Behaviors and Mechanical Features in Friction Stir Welding Process, Int J AdvManufTechnol, 35, 86-100

Zhang, Z., \& Zhang, H. W. (2009). Numerical Studies on the Effect of Transverse Speed in FrictionStirWelding, Materials and Design, 30, 900-907

Zhang, Z., \& Zhang, H.W. (2009). Numerical studies on controlling of process parameters in friction stir welding, Journal of Materials Processing Technology, 209, 241-270

Zhao, Y., Huang, X., Li, Q., Huang, J., \& Yan, K. (2015). Effect of Friction Stir Processing with $\mathrm{B}_{4} \mathrm{C}$ Particles on the Microstructure and Mechanical Properties of 6061Aluminum Alloy, The International Journal of Advanced Manufacturing Technology, 78, 1437-1443 